\title{
Analyzing the Trend of Chinese Real Estate Under the Epidemic Era by Comparing the Real Estate Markets Between China and Japan
}

\author{
Guanhua Qu
}

Jinan Foreign Language School, Jinan 250000, China

Email: quguanhua1219@163.com

\begin{abstract}
This paper will discuss about the China's real estate, the comparison of real estate between China and Japan, and analyzing China's real estate policies and the future trend of the real estate. First, this paper will compare the differences between Japan and China's real estate markets in different aspects. Then, analyze the Chinese government's real states policies by using the analysis of the "destocking policy". Through the analysis, this paper will give the future trend of the fluctuation of the real state maker after the important turning point in the COVID-19 era.
\end{abstract}

Keywords: Property-value bubble, investment in property, regulations of real estate, investment guide, development of China

\section{INTRODUCTION}

Under the COVID-19, as people's income changes, more and more people begin to change their view on the real estate market and call for reform. They also think that the bubble in China's property market could collapse just like Japan did in the 1990s. This paper discusses the idea by comparing the real estate market between China and Japan, and analyzing the latest policies afters made by Chinese government. This paper comes up with the results that we can't just simply compare the China's and Japan's real estate market, and after the GDP was increased by stimulate the real estate market, Chinese government realized that the increase in the price of houses will bring some problems, especially under the influence of the COVID-19. This paper also comes up with some solutions and suggestions for China's real estate market after analyzing the reason of the increase of the houses' price.

\subsection{Similarities Between China'S and Japan'S Real Estate Market}

\subsubsection{The development of the economic is similar}

After Japan going through the shadow of war, the economic was developed in a high speed, also the price of the houses. Also, after the reform and opening up, the China's economy has maintained a growth rate higher than world average, during this period, the real estate market has also obtained sufficient development and developed rapidly after 15 years of loose economic policies such as destocking. [1]

\subsubsection{Investment philosophy of real estate}

Both China and Japan are East Asian countries, and they have similar investment reasons for real estate. For Japan, because stability is the consensus for Japan, the banks in Japan were more restricted, means they cannot offer attractive investment projects. Because Japan's economy has developed rapidly, according to capital profit-driven, a large amount of money will go into the real estate market and lift the price. That formed the Japanese real estate bubble. For China, most of the people who buy more than one house property due to 
investment goal are the first group of entrepreneurs in China. Due to their weak education background and weak awareness of financial management and investment knowledge, these people are more likely to make stable and low-risk investment. And the real estate can be a good choice, especially after a series of national measures to benefit the real estate. After those policies, more and more people began to believe in the appreciation ability of the real estate, so a large amount of money went into the real estate market.

\subsubsection{Both countries are facing external pressure}

Another similarity between those two countries is that both China and Japan are export-oriented countries. Before Japan signed the Plaza Accord, Japan exported a large amount of goods such as car spots to the United States, resulting in a large trade surplus. In order to reduce the trade deficit of the United States, the United States signed the Plaza Treaty in Japan in order to strengthen the yen. China is also under the pressure of the strengthen of the RMB. Like Japan, China also exports a lot of goods to the United States, which leads to the U.S. trade deficit. Although Chinese-made goods are more affordable to the American people, the United States has repeatedly put pressure on the RMB to protect certain industries and for some political reasons. They have threatened China to impose higher tariffs on Chinese imports if the RMB does not appreciate. When the currency appreciates, international capital will flow into the region with a higher exchange rate to maintain its value, which will further push up the housing price.

\subsection{The Differences between China's and Japan's Real Estate Market}

\subsubsection{The increasement of house price in two countries is different}

Even though the current housing price in China is still growing, the housing price between different cities in China has obvious differences, the housing price in different area in the same city also different obviously. Naturally, some first-tier cities, such as Beijing, Shanghai, Guangzhou and Shenzhen have the highest housing prices, in the same city is also the area has the fastest inflow of talent and capital have the highest housing price. For example, housing prices in different districts of Jinan sometimes differ by $50 \%$, and even though housing prices in Jinan continue to decrease, housing prices in the Lixia districts still tend to stabilize and rise slightly under the epidemic. In Japan, not only did prices rise faster than in China, but they also rose for a longer period of time. In general, China's housing prices are much lower than Japan's, both in terms of price and increase.

\subsubsection{Two countries have different strategies to cope with currency appreciation}

Japan accumulated a lot of bubbles because its currency appreciated greatly after the Plaza Accord. China has capital controls that prevent the RMB from being converted directly into foreign currency, so it won't appreciate as much as Japan because of intentional outside intervention.

\subsubsection{The reason for house demand different in the two countries}

China and Japan are at different stages of urbanization. When the real estate bubble occurred in Japan, the urbanization process was approaching its end, and the demand for housing in rigid demand had been basically met. However, China is still in the stage of rapid development, and housing in rigid demand is still the main reason of buying a house. [2]

\subsubsection{Conclusion from the comparations}

Although there are many similarities between the real estate markets of China and Japan, however, there are many differences that indicate that the real estate maker between China and Japan cannot be simply compared.

\subsection{The Danger of an Overheated Real Estate}

China's real estate market is particularly important for China's development. First, when a large number of people buy more than one house because of their attitude of investment and without selling or renting them out, a large amount of resources will be wasted. People who want to buy a house are discouraged because of the housing price, while a large number of houses are piled up in the hands of a few people, which is a great waste of resources. [3]

Real estate also has a high connection with other industries. While the development of the real estate driving the rapid development of building materials market, because the capital was driven by profit, a large amount of capital flows into the real estate market, which will decrease the investment in other fields.

More and more people follow the trend to buy houses or invest in real estate. That will bring a large number of loans, which will increase the risk of bankruptcy of banks. Banks have to face liquidity problems. That may also produce some bad debts which will threat the health of the banking system, and even cause debt crisis, bring risks to the whole society.

Therefore, for the healthy and sustainable development of China's economy in the future, it is imperative to regulate real estate market. 


\subsection{China's Tools of Regulating the Real Estate Market}

If people want to be a local official, you need to show political achievements in order to get promoted, and local GDP is a good indicator. That's why the local government encourage the development of real estate. Due to the need of real estate construction, the development of real estate often promotes the development of some real industries, such as building materials industry. And the government revenue from land sales can also be used to build infrastructure, which will also boost the real economy and create a lot of jobs. In such an environment that attaches importance to infrastructure construction and GDP, China has come up with some policies to stimulate the real estate industry, which also proves that policy is an important factor to influence China's real estate industry. We can see that if Chinese government want to regulate real estate market, they will start with policies.

As for the regulation through policies, the most representative one is the destocking policy around 2016 [4]. China's housing price also changed a lot during that period. Since China began to decrease the interest rates in 2014, the reserve ratio and interest rate have been lowered for five times to guide capital into the market. In addition, policies such as reducing the proportion of down payment and abolishing restrictions on buyers from other cities have led to a rapid rise in housing prices. Prices in first-tier cities rose about 23.85 percent, when the real estate market was so hot that some residents who wanted to buy houses had to queued overnight at the opening of the market. Moreover, it's easy to see that the cities with a rising concentration that most of these cities are the provinces with large migrant population, the "front positions" of the reform and opening up to attract foreign investment, which also shows the high connection between housing price and development and population. However, the housing prices in some period of fourth or fifth-tier cities have continued to fall during this period, which reflects the dominance of the new demands of housing.

\subsubsection{Regulate the flow of people into cities}

The cause of the high housing prices in some big cities can be attributed to the conflict between the influx of people and the scarcity of land and jobs. Most of the new jobs in big cities are concentrated in high-tech industries. As jobs become more and more difficult to find in big cities, more young people choose to go back to their hometown to work after graduation from university, where there are suitable jobs and relatively low prices. The Chinese government has followed the trend. Chinese government recently come up with a number of rural employment benefits for small cities to encourage people to return home and start businesses.[5]
For example, the policies call on young college students to return to their hometown, build rural areas, and properly settle veterans for re-employment. In addition, the recent popular model of live-streaming and sell goods through Internet break the barriers between production and sales through the Internet, so that high-quality goods in some remote places can be sold. These policies not only promoted the development of small cities and rural areas, but also controlled the inflow of urban population to cities and alleviated the contradiction between human and land.

\subsubsection{Adjust house purchase policies}

In the last few years of China's property boom, the government immediately declared that "houses are for living, not for speculation," and began cracking down on property speculation everywhere, including the ever-popular real-estate syndicate. Some of these policies are very effective.

For example, the policy of restricting the purchase of real estate in different places has effectively prevented the real estate purchase for the purpose of investment all over the country, and prevented a large number of investments demands from flooding into a city and crowding out the limited land resources and driving up the housing price. According to some cities' policy, people who want to buy a house in the city must be a resident in the city. This blocked the channel of property speculation from the origin, so that capital from other areas will not have a greater impact on local housing prices.

The policy of purchase restriction also plays a great role. The policy of purchase restriction can limit the number of individual purchases. When a person changes his house to improve his life quality, he needs to deal with the old house first, which increases the number of houses in circulation in the market.

Some policies have raised the threshold for house purchases by raising the minimum down payment required. In some cities, the down payment on a second house can be as high as 60 percent, and the loan term will be shortened to 25 years.

All these policies are aimed at the original problems of reducing the waste of resources because of the scarcity of land. By increasing the flow of property in the market and reducing the waste of resources caused by the purchase of multiple property for investment purposes in other places.

\subsubsection{Evaluation of these policies}

These policies did not severely crack down on the real estate market by blindly took measures to reduce prices. This indicates that the Chinese government has realized that this development mode is not conducive to 
the long-term healthy development of China's economy, but it did not adopt strict policies like Japan.

July 30, they held a meeting of the Political Bureau of the CPC Central Committee, reaffirmed the government's position, "the house was meant to live not to fry", central will not use the real estate as a means of short-term stimulus, but use the real estate as a cornerstone and stabilizer for long-term stable and healthy economic development. And accelerate the establishment of long-term management mechanism will be. This once again proves that the golden age of China's real estate market has passed and has entered a period of up and down under the regulation of the government. It is unrealistic to expect to gain much profit from real estate investment.

\subsection{Real Estate Investment Under Covid-19}

In 2020, the COVID-19 outbreak the estate market, at the same time, it also brings the opportunities for real estate market to reform. First of all, the large-scale closure caused by COVID-19 has seriously affected households' income. In April, the average income of households decreased by $22.5 \%$.[7] This also leads to changes in Chinese household investment. Due to the decline of household income, some families may shelve or give up their plans to buy their next house and turn to some lower-risk financial investments, such as funds or government bonds. And the data also showed that funds investment groups began to present a trend of young and highly educated, this means more and more people in Chinese investment market have a better understanding and knowledge about the investment, and there are more and more people are beginning to realize that it's almost impossible to gain profit from the real estate market today. And that means that reduce the investment in real estate means will increase the investment in the financial markets.

\subsection{Suggestions On China'S Real Estate Market}

\subsubsection{Financial institutions should guide capital correctly}

To prevent the question of 'what Chinese families can invest their money in if they don't buy a house'. In my opinion, financial institutions should improve and launch more low-risk household investments to absorb this part of capital and maximize their utilization, so as to prevent the waste of resources or being forced to flood into the real estate market again. Banks should also adjust the real estate loan policies flexibly, reduce the interest or down payment of the houses they need appropriately, increase the cost of owning more than one set of real estate and restrain the purchase of more than one set of real estate, such as increasing the ratio of down payment in loans and the interest of loans.

\subsubsection{Improve real estate policies}

At the same time, the government should continue to improve housing policies. First of all, the government should start from the origin of the problem - land. The government should adjust the land supply policy flexibly to achieve the goal of the control of real estate prices reasonable. At the same time, it should also track the use of land well, prevent developers from wasting land resources by developing the land ineffectively after they brought the land and crackdown property speculation.

\subsubsection{Government should improve the management of exchange rate and foreign capital}

We should also guide investment correctly, increase the diversity of investment, use capital correctly and reduce the waste caused by idle capital. Also, strengthen the foreign exchange control, give correct guidance to foreign capital, and use it conductively to development, and guide it to flow into the real economy and operation also the high technology industries. At the same time, Chinese government should keep the RMB exchange rate stable for long period and avoid huge changes in the exchange rate like Japan.

\section{CONCLUSION}

Through the analysis of this paper. First, it rejects the view that the real estate market in China is almost the same as the estate market in Japan. Also, by analyzing the influence of the real estate market on the economy at the present stage, it is concluded that the Chinese government will certainly rectify the chaos of the real estate market. But because of the real estate market in China's economic acts as the stabilizer, the Chinese government will not cut the estate market immediately like Japan. And the decrease of household income changed by COVID-19 will also urge China to have more effective policies that start from the fundamental contradiction. This confirms the fact that house prices cannot keep rising forever, and the simple rise in house prices is only a temporary bubble brought on by irrational investment, which will disappear when rational investments and economic activities increase.

\section{ACKNOWLEDGMENT}

First and foremost, I would like to show my deepest gratitude to my teachers and professor in my summer school, who have provided me with valuable guidance in every stage of the writing of this thesis. Further, I would like to thank all my friends and classmates for their encouragement and support. Without all their 
enlightening instruction and impressive kindness, I could not have completed my thesis.

\section{REFERENCES}

[1] R. Fan.(2012). Comparative Analysis of Real estate bubbles in China and Japan. knowledge economy,87-88.doi:CNKI:SUN:ZZJJ.0.2012-05-05 9.

[2] Z. Liu.(2013). Try to analyze the difference of real estate industry between China and Japan. real estate industry of China : The theory of version,7-7.

[3] S. Chen.(2020). Discussion on the real estate bubble in China. National circulation economy (03),120-121.

doi:10.16834/j.cnki.issn1009-5292.2020.03.054.

[4] Y. Qian.(2016). "Destocking" under the Real Estate Policy Easing Cycle. China Real Estate Finance(Z1),46-52. doi:.

[5] G. Li. (11.4 2020). "Li Gan:China's household asset allocation should not be centered on real estate" Retrieved from https://mbd.baidu.com/newspage/data/landingsuper ?context=\%7B\%22nid\%22\%3A\%22news_102474 $61410410991838 \% 22 \% 7 \mathrm{D} \&$ _type $=1 \& \mathrm{p} \_$from $=4$

[6] Tencent. (7.26 2020). https://new.qq.com/omn/20200726/20200726A07F A100.html

[7] Economic Information Daily. (10.29 2020) http://www.xinhuanet.com/fortune/2019-10/29/c_1 125164214.htm 